\title{
Characterization of neuronal differentiation factor(s) produced by Kagura-2 cells established from aflatoxin $B_{1}$-induced rat hepatoma
}

\author{
Naomitsu HiRano*1,2, Eriko TANAKA*1, Kotaro AKAOGI*1 \\ and Fumio TASHIRO*1
}

\begin{abstract}
平野直光 ${ }^{* 1,2}$ ，田中恵利子*1，赤荻幸太郎*1，田代文夫*1：アフラトキシン $\mathrm{B}_{1}$ 誘発 ラット肝癌由来 Kagura-2 細胞が産生する神経分化誘導因子について
\end{abstract}

\begin{abstract}
Summary
Recently we have demonstrated that the growth of Kagura-2 cells established from aflatoxin $\mathrm{B}_{1}\left(\mathrm{AFB}_{1}\right)$-induced rat hepatoma was markedly stimulated by glucocorticoids (GCs). To investigate a possible role of GCs in the growth of Kagura-2 cells, we studied the effect of conditioned medium (CM) prepared from Kagura-2 cells on the neuronal differentiation of pheochromocytoma (PC12) cells.

Kagura-2 cell-CM caused in PC12 cells a number of physiological changes which mimic the nonreplicating sympathetic neuron-like cells, including induction of neurite extension and acetylcholinesterase activity. The neuronal differentiation factor(s) in $\mathrm{CM}$ were inactivated by the treatments of trypsin, acetic acid, dithiothreitol and heat. The molecular weights of factor(s) ranged from 6,000 to 14,000 on the basis of experiments using various molecular weight cutoff dialysis tubing and gel filtration.
\end{abstract}

$\mathrm{AFB}_{1}$, a metabolite of Aspergillus flavus, is well known for its potency in hepatocarcinogenesis in experimental animals. $\mathrm{AFB}_{1}$ as well as hepatitis virus has also been implicated in the etiology of human liver cancer, on the basis of statistically significant correlation between the increased occurrence of liver cancer and the consumption of grains contaminated with $\mathrm{AFB}_{1}$ in Asia and Africa areas ${ }^{1)}$.

We have demonstrated the over-expression of $\mathrm{c}$ -

*1 Department of Biological Science and Technolonogy, Faculty of Industrial Science and Technology, Science University of Tokyo (2641 Yamazaki, Noda-shi, Chiba 278). 東京理科大学基礎工学部生物工学:科（开278 千葉 県野田市山崎2641)

*2 Department of Toxicology and Microbial Chemistry, Faculty of Pharmaceutical Sciences, Science University of Tokyo (12 Ichigaya Funagawaramachi, Shin juku-ku, Tokyo 162). 東京理科大学菂学部毒性学・微生物化学教室 （干162 東京都新宿区船河原町12） myc and c-Ha-ras mRNA in $\mathrm{AFB}_{1}$-induced rat hepatocellular carcinomas and cultured cell lines ${ }^{2)}$. Subsequently the activation of c-ras oncogene family by point mutation in $\mathrm{AFB}_{1}$-induced rat liver cancers has been reported by McMahon et al. ${ }^{3)}$ and Sinha et al. ${ }^{4)}$ We have also demonstrated the modulation of hormonal induction of tyrosine aminotranferase and $\mathrm{GC}$ receptors by $\mathrm{AFB}_{1}$ and sterigmatocystin in the rat hepatoma cell line ${ }^{5)}$. Most recently we have reported that the colony formation of Kagura-2 cells in soft agar was markedly enhanced by GCs, and the cells showed the GC-dependent growth in serumfree medium accompanying with the transient expression of c-myc gene ${ }^{6, i)}$. Moreover $\mathrm{Lu}$ et al. ${ }^{8)}$ have demonstrated that the growth-stimulatory activity of various androgens or GCs on $\mathrm{SC}-3$ cells established from mouse mammary tumor was mediated through a FGF-like peptide in an autocrine mechanism. 
We therefore studied the effect of Kagura-2 cell$\mathrm{CM}$ on PC12 cells which differentiate into sympathetic neuron like cells in the presence of growth factors such as NGF, acidic FGF, basic FGF and IL $-6^{9,10)}$. In this paper we describe the features of neuronal differentiation factor(s) produced by Kagura-2 cells.

\section{Materials and Methods}

Preparation of CM from Kagura-2 cells Kagura2 cells were cultured in collagen-coated dishes containing Dulbecco's modification of Eagle's medium (DMEM) with $10 \%$ fetal calf serum (FCS) in a humidified $\mathrm{CO}_{2}$ incubator at $37^{\circ} \mathrm{C}$ and the medium was changed every two other days. When the cells were grown up to $70-80 \%$ confluence, the medium was changed to serum-free medium and cultured for additional 2 days. This serum-free medium will be referred to as Kagura-2 cell-CM. The supernatant, after centrifugation at $5,000 \times \mathrm{g}$ for $30 \mathrm{~min}$, was filtered through a $0.22 \mu \mathrm{m}$ nitrocellulose filter and used for experiments.

Neuronal differentiation of PC12 cells by CM PC12 cells were plated at $2-3 \times 10^{4}$ cells per collagencoated $35-\mathrm{mm}$ dish and cultured in the growth medium consisted of DMEM with $10 \%$ FCS and $5 \%$ horse serum. One day after the plating, the growth medium was changed to the growth medium supplemented with Kagura-2 cell-CM (growth medium: $\mathrm{CM}=1: 2, \mathrm{~V} / \mathrm{V}$ ) and cultured for 6 days with two changes of the medium.

\section{Results and Discussion}

Under routine culture conditions, PC12 cells proliferated as round chromaffin-like cells (Fig. 1-A). By the addition of NGF to the growth medium, PC12 cells flattened and began to send out short neurites within a few days, and after several days proliferation ceased and the majority of the cells formed a network of long and branched neurons (Fig. 1-B). As shown in Fig. 1-C, in Kagura-2 cell-CM supplemented growth medium, PC12 cells remained alive, and following a lag of 3 days, also started to extend neurites.

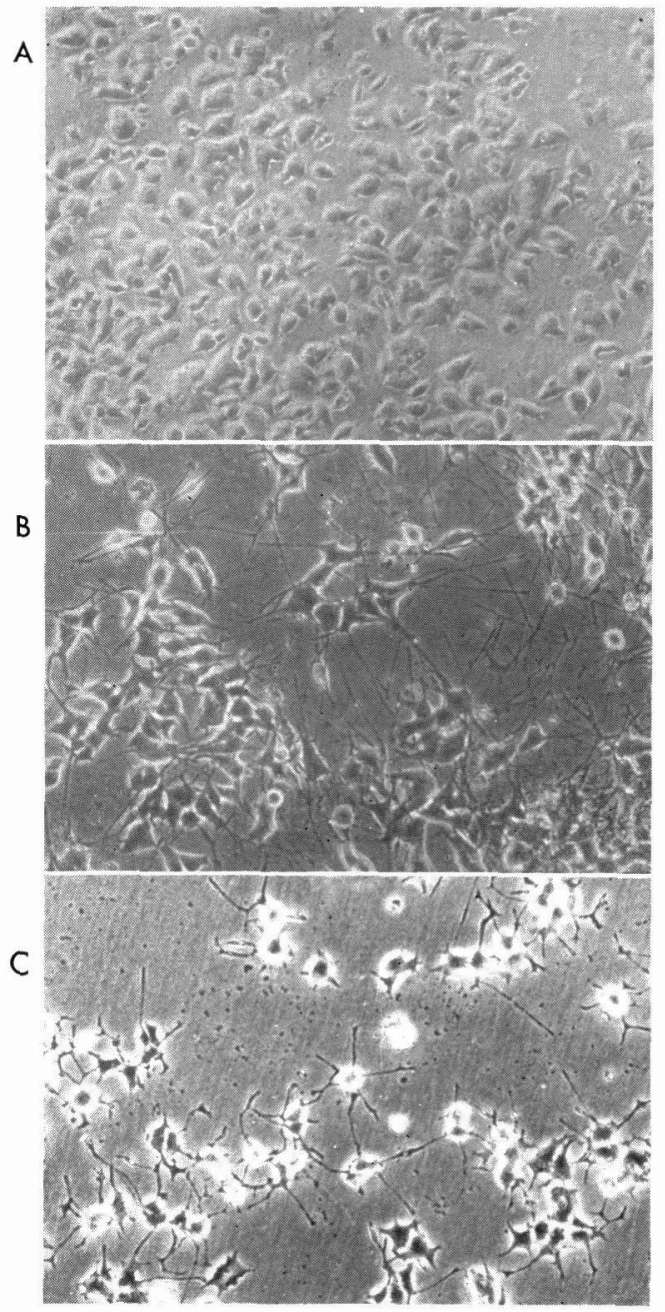

Fig. 1. Induction of the neuronal morphology of PC12 cells by NGF and Kagura-2 cell-CM. PC12 cells were maintained in growth medium (A), in growth medium supplemented with $50 \mathrm{ng} / \mathrm{ml}$ of mouse $2.5 \mathrm{~S} \mathrm{NGF}$ for 6 days (B) or growth medium supplemented Kagura-2 cell-CM as described in "Materials and Methods" for 6 days (C). The photographs were taken under phasecontrast optics. Magnification, $\times 200$.

To determine whether the changes induced by Kagura-2 cell-CM are involved in neuronal differentiation, we investigated whether neuron-specific properties known to be induced by NGF and cAMP are also induced by CM obtained from Kagura-2 
Table 1. Acetylcholinesterae ativities in PC12 cells treated with well known neuronal differentiation factors and Kagura-2 cell-CM

\begin{tabular}{|c|c|c|c|}
\hline Treatment & & $\begin{array}{l}\text { Acetylcholinesterase activity } \\
\text { (nmol/min/mg protein) }\end{array}$ & $\begin{array}{c}\text { Ratio } \\
\text { (treated/control) }\end{array}$ \\
\hline \multicolumn{4}{|l|}{ Control } \\
\hline In growth medium & $(n=9)$ & $17.8 \pm 0.49$ & 1.00 \\
\hline NGF & $(n=5)$ & $37.3 \pm 1.84$ & 2.10 \\
\hline $\mathrm{Bt}_{2} \mathrm{cAMP}$ & $(n=6)$ & $39.9 \pm 2.19$ & 2.24 \\
\hline basic FGF & $(n=3)$ & $17.9 \pm 1.18$ & 1.01 \\
\hline \multicolumn{4}{|c|}{ Kagura-2 cell-CM generated in } \\
\hline DMEM with $10 \%$ FCS & $(n=7)$ & $27.9 \pm 0.72$ & 1.57 \\
\hline DMEM without FCS & $(n=5)$ & $34.0 \pm 1.75$ & 1.91 \\
\hline \multicolumn{4}{|c|}{$\begin{array}{l}\text { PC12 cells }\left(5 \times 10^{5} \text { cells } / 35-\mathrm{mm} \text { dish }\right) \text { were treated with } 50 \mathrm{ng} / \mathrm{ml} \mathrm{NGF}, 1 \mathrm{mM} \mathrm{Bt}{ }_{2} \mathrm{AMP}, 5 \\
\mathrm{ng} / \mathrm{ml} \text { basic FGF or Kagura- } 2 \text { cell-CM for } 6 \text { days as described in "Materials and Methods.", } \\
\text { A colorimetric enzyme assays were performed with homogenates from } 3 \text { to } 9 \text { independent } \\
\text { cultures for each group by the method of Ellman et al. }{ }^{11)} \text { Data are given as mean } \pm \text { s.e. } n \text {, } \\
\text { number of experiments. }\end{array}$} \\
\hline
\end{tabular}

cells in PC12 cells. First, we observed that PC12 cells treated with $\mathrm{CM}$ contained higher activities of acetylcholinesterase (as did NGF- or cAMP-treated cells) than did untreated cells (Table 1). Second, Kagura-2 cell-CM induced the expression of c-fos gene within $30 \mathrm{~min}$, although the level of induction was less than those by NGF and cAMP (data not shown).

The neuronal differentiation factor(s) were completely inactivated by the treatments of $100 \mu \mathrm{g} / \mathrm{ml}$ trypsin for $30 \mathrm{~min}$ at $37^{\circ} \mathrm{C}$, those of $0.17 \mathrm{M}$ acetic acid for $5 \mathrm{~min}$ at room temperature, those of $65 \mathrm{mM}$ dithiothreitol for $2 \mathrm{hr}$ at room temperature or heating for $5 \mathrm{~min}$ at $100^{\circ} \mathrm{C}$. The molecular weights of the factor(s) ranged from 6,000 to 14,000 on the basis of experiments using various molecular weight cut-off dialysis tubing and Sephadex G-200 gel filtration.

These data show that Kagura-2 cells produce the neuronal differentiation factor (s) which are acidunstable and relatively low molecular weight protein like as NGF. We are now investigating whether the factor(s) are essential for Kagura-2 cell growth as an autocrine growth factor.

\section{References}

1) Wogan, G. N.: Aflatoxin carcinogenesis, in "Methods in Cancer Research, Vol. III",
Busch, H., ed., p. 309-344 (1973), Academic Press, New York.

2) Tashiro, F., Morimura, S., Hayashi, K., Makino, R., Kawamura, H., Horikoshi, N., Nemoto, K., Ohtsubo, K., Sugimura, T., Ueno, Y. : Biochem. Biophys. Res. Common., 138, 858 (1986).

3) McMahon, G., Hanson, L., Lee, J. J., Wogan, G. N.: Proc. Natl. Acad. Sci. USA, 83, 9418 (1986).

4) Sinha, S., Webber, C., Marshall, C. J., Knowles, M. A., Protecter, A., Barras, N.C., Neal, G. E.: Proc. Natl. Acad. Sci. USA, 85, 3673 (1988).

5) Horikoshi, N., Tashiro, F., Tanaka, N., Ueno, Y.: Cancer Res., 48, 5188 (1988).

6) Morimura, S., Tashiro, F., Ueno, Y.: Chem. Pharm. Bull., 38, 460 (1990).

7) Hirota, K., Hirano, N., Morimura, S., Nemoto, K., Ueno, Y., Tashiro, F.: Proc. Jpn. Assoc. Mycotoxicol., 30, 29 (1989). (in Japanese)

8) Lu, J., Nishizawa, Y., Tanaka, A., Nonomura, N., Yamanishi, H., Uchida, N., Sato, B., Matsumoto, K.: Cancer Res., 49, 4963 (1989).

9) Greene, L. A., Tischler, A. S.: Proc. Natl. Acad. Sci. USA, 73, 2424 (1976).

10) Sato, T., Nakamura, S., Taga, T., Matsuda, T., Hirano, T., Kishimoto, T., Kaziro, Y.: Mol. Cell. Biol., 8, 3456 (1988).

11) Ellman, G. L., Courtney, K. D., Andres, Jr., Fetherstone, R. M.: Biochem. Pharmacol., 7, 88 (1961). 